\title{
Analisis Penerapan Virtual Laboratorium Versus Reality Laboratorium
}

\author{
Apid Hapid Maksum \\ Fakultas Teknik \\ Program Studi Teknik Industri \\ Universitas Singaperbangsa Karawang \\ hapidmaksum@gmail.com
}

\author{
Yuliarman Saragih \\ Fakultas Teknik \\ Program Studi Teknik Elektro \\ Universitas Singaperbangsa Karawang \\ yuliarman@yahoo.com
}

\begin{abstract}
Abstrak - Pembelajaran kimia memiliki kegiatan pembelajaran teori dan praktikum, Infrastruktur laboratorium merupakan bagian yang sering menjadi hambatan utama. Secara umum penelitian ini bertujuan untuk memberikan alternatif solusi pada keterbatasan sumberdaya pembelajaran di Perguruan Tinggi khususnya prakikum, Secara khusus penelitian ini dilakukan untuk menganalisa penerapan virtual laboratorium dan reality laboratorium dengan metode eksperimental. Hasil analisa dari 15 sampel mahasiswa Universitas Singaperbangsa Karawang yang diberikan 7 jenis pertanyaan adalah, penerapan virtual lab dapat mengurangi kesalahan dan kecelakaan kerja saat praktikum, selain itu penerapan virtual lab juga dapat menjadi solusi bagi perguruan tinggi yang memiliki permasalahan dengan fasilitas laboratorium, namun virtual lab tidak bisa diterapkan secara penuh menggantikan reality lab, hal ini dikarenakan tingkat pengalaman dan keterampilan praktikan dengan virtual lab tidak sebaik dengan reality lab. Praktikan tidak secara langsung berinteraksi dengan alat dan bahan kimia, sehingga virtual lab lebih efektif jika diterapkan sebagai praktikum pendahuluan untuk menunjang pemahaman praktikan dalam melakukan praktikum.
\end{abstract}

Kata kunci - Virtual Lab; Reality Lab; Praktikum

\section{PENDAHULUAN}

Pembelajaran kimia memiliki kegiatan pembelajaran teori dan praktikum, selain memerlukan suatu kerangka pembelajaran juga dibutuhkan suatu media pembelajaran sebagai pendukung pembelajaran kimia, terutama pada pembelajaran praktikum dibatasi pengalokasian waktu terhadap penjelasan materi ajar, pengarahan prosedur praktikum ataupun penarikan kesimpulan yang mempengaruhi proses pembelajaran dan tingkat pemahaman peserta didik terhadap materi pembelajaran kimia [1]. Pembelajaran kimia mempunyai kegiatan pembelajaran teori dan praktikum, selain memerlukan suatu kerangka pembelajaran juga dibutuhkan suatu media pembelajaran sebagai pendukung pembelajaran kimia [2].

Penelitian ini dilatarbelakangi oleh kegiatan pembelajaran praktikum yang membutuhkan praktikum pendahuluan untuk mengurangi kesalahan-kesalahan yang mungkin terjadi pada saat praktikum sesungguhnya dilakukan yang dapat berakibat pada keamanan dan keselamatan praktikan [3]. Selain itu ketersediaan sumber daya laboratorium yang belum cukup memadai tidak akan menjadi masalah lagi, serta memudahkan pendidik untuk memberikan arahan pada proses pembelajaran praktikum agar mempunyai kondisi pembelajaran yang aktif [4]. Salah satu materi ajar yang mempunyai kegiatan praktikum yakni asam basa. Materi asam basa merupakan suatu konsep yang konstekstual maka kegiatan praktikum menjadi stimulus peserta didik dalam memahami konsep asam basa [5]. 
Infrastruktur laboratorium merupakan bagian yang sering menjadi hambatan utama . Pengadaan suatu infrastruktur tidak hanya masalah biaya dan waktu tetapi juga kelanjutan pengelolaan yang cukup kompleks, terutama bagi perguruan tinggi dengan sumberdaya (lahan, pekerja, dana dan waktu) yang terbatas. Beberapa hal lain yang dipandang menjadi permasalahan dalam pengelolaan laboratorium antara lain seperti (1) Sumber Daya Laboratorium: meliputi peralatan praktikum, pekerja/teknisi laboratorium, dosen pembimbing, asisten praktikum, tempat praktikum, (2) Manajemen Laboratorium: Bagaimana pengelolaan waktu praktikum menjadi mudah, baik dari sisi pengelola maupun dari sisi pengguna laboratorium (mahasiswa). Bagaimana mahasiswa lebih maksimal menggunakan jam praktikum, (3) Biaya Praktikum: Bagaimana menekan biaya praktikum menjadi minimal, mengingat harga bahan praktikum yang terus mengalami kenaikan, tentunya dengan tidak mengurangi kualitas hasil praktikan, serta (4) Peningkatan mutu/kompetensi mahasiswa dengan sumber daya terbatas di laboratorium [6][7]

Secara umum penelitian ini bertujuan untuk memberikan alternatif solusi pada keterbatasan sumberdaya pembelajaran di Perguruan Tinggi, dengan memberikan kemudahan pada mahasiswa untuk melakukan praktikum tanpa terikat waktu maupun kelas konvensional di laboratorium yang mempunyai keterbatasan jam praktikum dan alat, bahan sebagai sarana pembelajaran di laboratorium. Berdasarkan model Laboratorium Virtual yang dibuat dalam penelitian ini, dengan dilakukan secara online mahasiswa bisa melakukan download materi, tutorial, maupun upload hasil tugas praktikum yang dikerjakan. Sistem yang dijalankan membuat Laboratorium seolah buka 24 jam kerja, praktikum dapat dilakukan kapan saja dengan access online [8].

\section{METODE}

Penelitian analisa penerapan virtual lab vs reality lab ini menggunakan metode experimental dengan sampel sejumlah 15 orang mahasiswa yang berperan ganda, sebagai kelompok eksperimen dan kelompok kontrol. Kelompok eksperimen berperan melakukan praktikum menggunakan virtual lab, dalam hal ini, virtual lab di desain dengan mengkolaborasikan software chemlab dan google classroom, sebagaimana yang terlihat pada Gambar 1 dan Gambar 2 Berikut ini

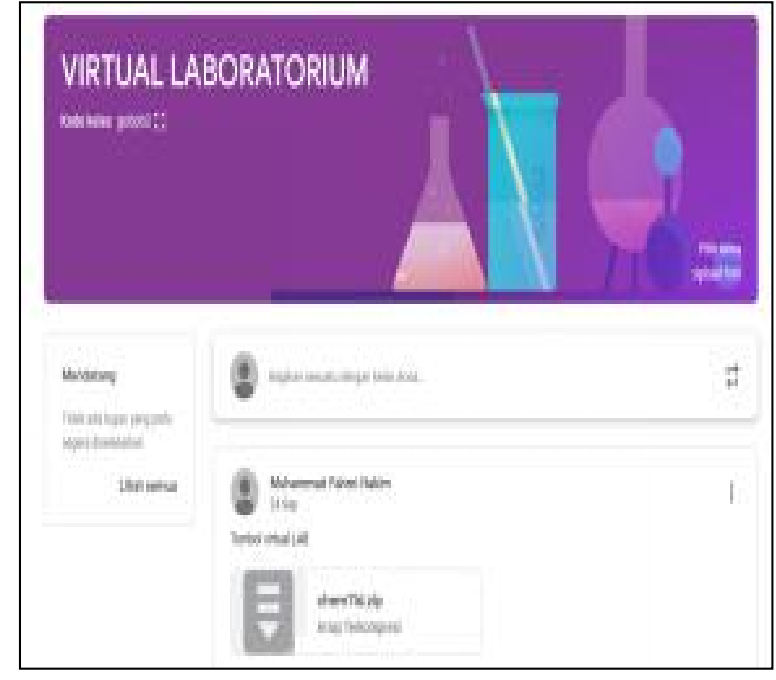

Gambar 1. Display Google Classroom Virtual Lab

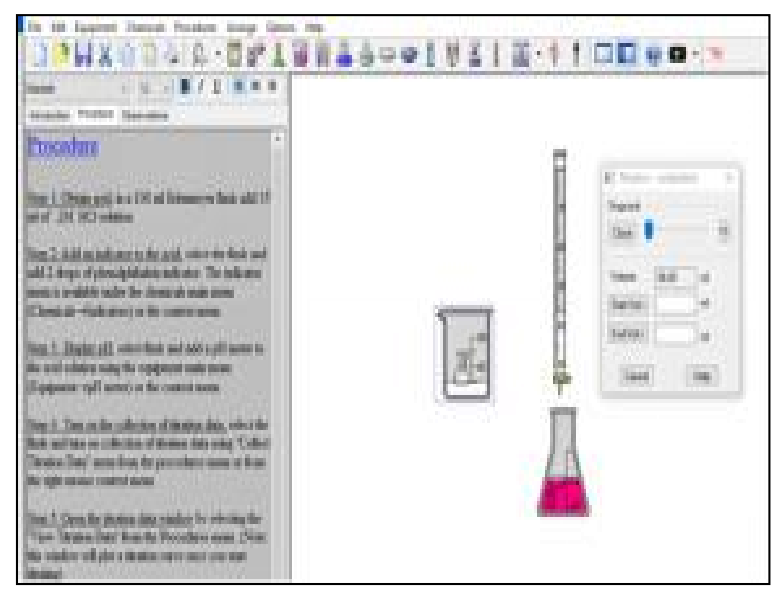

Gambar 2. Display Software Chemlab Dengan Sub-Bab Praktikum Titrasi Asam-Basa

Kelompok kontrol adalah sampel mahasiswa yang telah melakukan praktikum reality lab. Berdasarkan pengalaman dan pemahaman dari praktikum yang telah dilakukan, kemudian dijadikan sebagai kontrol untuk membandingkan praktikum virtual lab dan reality lab. Mekanisme pengambilan data yang dilakukan adalah dengan melakukan survey terhadap sampel. 15 sampel mahasiswa Universitas Singaperbangsa Karawang, diberikan 7 pertanyaan menggunakan google form dengan 5 pilihan jawaban: sangat tidak setuju, tidak setuju, kurang setuju, setuju, sangat setuju. pertanyaan yang diajukan terkait penerapan virtual lab dan reality lab. Analisis data dilakukan berdasarkan hasil presentase jawaban, khususnya jawaban dengan presentase tertinggi. 


\section{HASIL DAN DISKUSI}

Penelitian ini diawali dengan kegiatan praktikum reality lab oleh 15 sampel mahasiswa, kemudian dilanjutkan dengan kegiatan praktikum virtual lab. Data diperoleh dengan melakukan survei terhadap sampel, diberikan 7 pertanyaan. Dari 7 pertanyaan, Sampel mahasiswa di minta untuk memilih satu jawaban dari 5 pilihan jawaban: sangat tidak setuju, tidak setuju, kurang setuju, setuju atau sangat setuju. Hasil survei terhadap 15 sampel akan dibahas sebagai berikut:

\section{Pertanyaan 1}

Bagaimana pendapat anda jika virtual lab diterapkan sepenuhnya menggantikan reality lab?

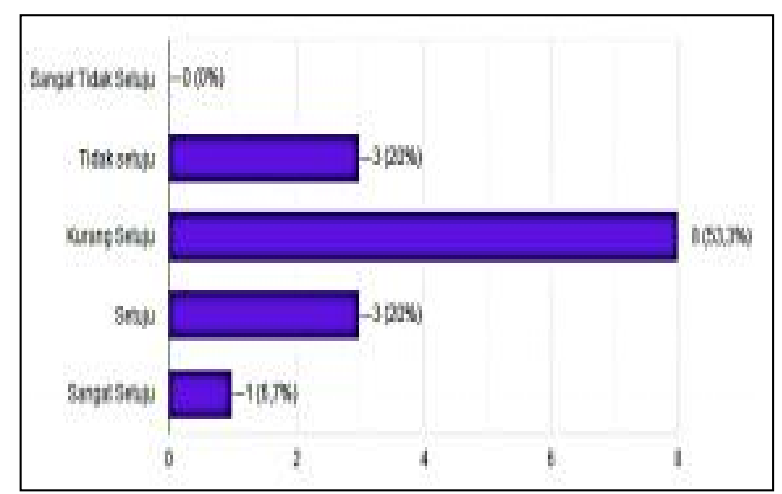

Gambar 3. Diagram Hasil Survei Pertanyaan 1

Penjelasan: Jawaban responden terbanyak adalah kurang setuju apabila virtual lab sepenuhnya menggantikan reality lab yaitu sebanyak 53,3\%. Jawabab senada juga ditunjukkan oleh responden yang memilih jawaban tidak setuju, yaitu sebesar $20 \%$, hal ini dikarenakan sebagian besar sampel beranggapa bahwa praktikum yang dilakukan berdasarkan virtual memiliki perbedaan dengan reality lab, terkhusus dari sisi pengalaman dan keterampilan motorik mahasiswa. Sedangkan sampel sebanyak 20\% menjawab setuju dan 6,7\% sangat setuju beranggapan bahwa di era digital sepeeti saat ini keterampilan digital sudah cukup menginterpretasikan pemahaman.

\section{Pertanyaan 2}

Virtual lab adalah solusi untuk mengatasi tidak tersedianya fasilitas reality lab?

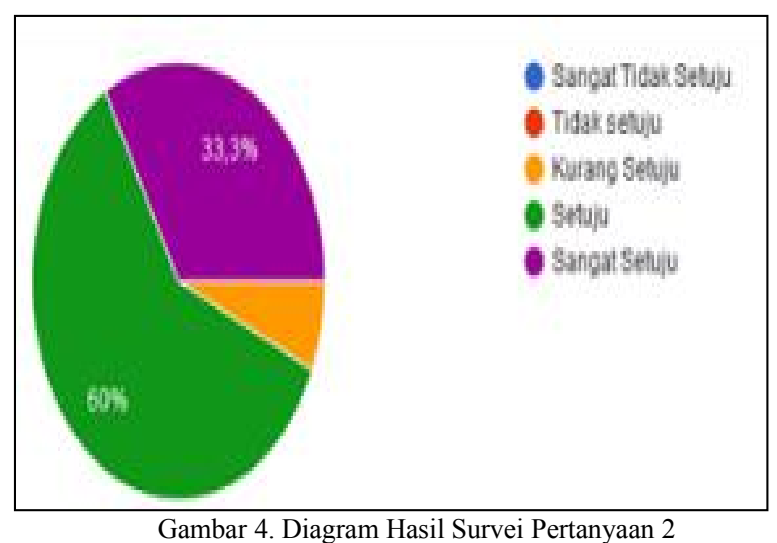

Penjelasan: dari diagram diatas terlihat bahwa jawaban responden terbanyak dengan persentase $60 \%$ menyatakan setuju bahwa virtual lab menjadi solusi untuk mengatasi tidak tersedianya fasilitas lab. Fasilitas lab merupakan salah satu permasalahan yang banyak di alami oleh perguruan tinggi, sistem menunggu persetujuan pengajuan alat dan bahan praktikum saling bertabfrakan dengan jadwal praktikum berjalan, sehingga hal ini dapat berakibat pada tidak terselenggaranya praktikum reality lab, hadirnya virtual lab dinilai sangat solutif untuk menyelesaikan permasalahan ini sebagai solusi alternatif.

Pertanyaan 3

Bagaimana jika virtual lab dijadikan praktikum pendahuluan (Pra) sebelum praktikum Reality Lab?

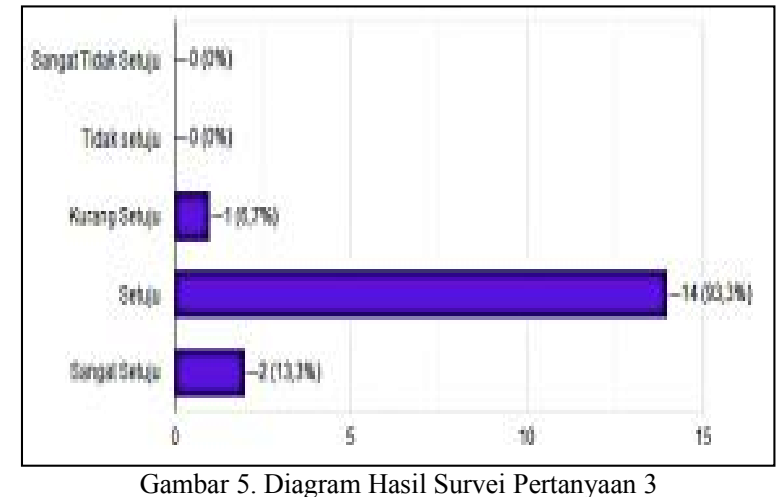


Penjelasan: sebagian besar responden menjawab setuju apabila virtual lab dijadikan praktikum pendahuluan sebelum reality lab, yaitu sebesar 93,3\% Hal-hal yang sering terjadi pada praktikum reality lab adalah terjadinya kesalahan-kesalahan yang dilakukan praktikan, baik itu kesalahan prosedur, perhitungan bahan, penggunaan alat bahkan terkadang sampai terjadi kecelakaan kerja. Penerapan virtual lab sebagai pre-praktikum dinilai akan menjadi solusi untuk mengurangi hal-hal yang tidak diinginkan tersebut.

\section{Pertanyaan 4}

Virtual lab dapat mengurangi resiko kesalahan dan kecelakaan kerja saat praktikum

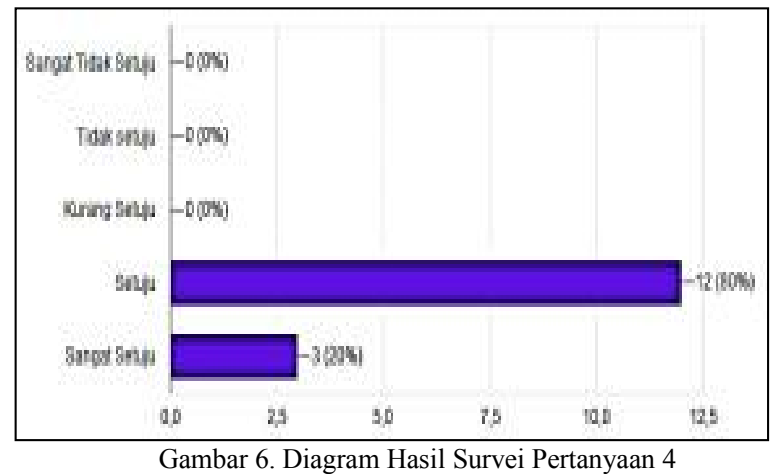

Penjelasan: responden setuju dengan pernyataan bahwa dengan menerapkan virtual lab dapat mengurangi resiko kesalahan dan kecelakaan kerja saat praktikum, yaitu sebesar $80 \%$, bahkan $20 \%$ responden menyatakan sangat setuju. Penerapan virtual lab akan meningkatkan keselamatan dan keamanan praktikan saat melakukan praktikum, hal ini dikarenakan praktikan tidak secara nyata berinteraksi dengan alat dan bahan kimia.

\section{Pertanyaan 5}

Reality lab memerlukan waktu praktikum yang lama sehingga kurang efektif dan efisien?

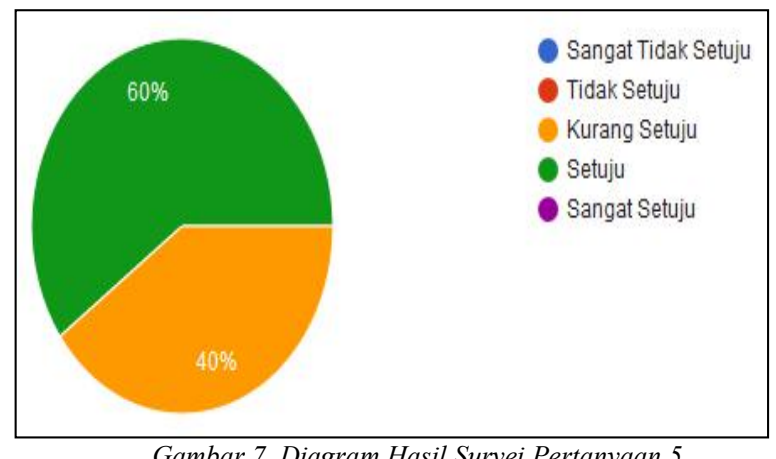

Gambar 7. Diagram Hasil Survei Pertanyaan 5
Penjelasan: Jawaban responden untuk pertanyaan ini terbagi 2 dengan selisih $10 \%, 60 \%$ responden menjawab setuju dengan pernyataan bahwa praktikum reality lab memerlukan waktu yang lama sehingga kurang efektif dan efisien, sedangkan sebanyak 40\% responden menjawab kurang setuju. Praktikum reality lab memerlukan waktu yang sesungguhnya sesuai dengan prosedur praktikum, akan tetapi keseluruhan waktu yang diperlukan sudah berdasarkan buku petunjuk praktikum yang tentu saja estimasi waktu yang digunakan sudah disesuaikan dengan jumlah sks praktikum.

\section{Pertanyaan 6}

Pemahaman dan pengalaman yang didapat dari praktikum virtual lab lebih baik dari pada reality lab?

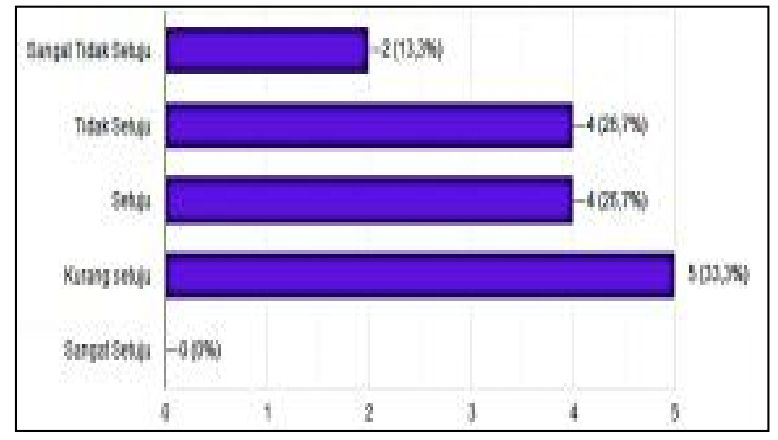

Gambar 8. Diagram Hasil Survei Pertanyaan 6

Penjelasan: Sebanyak 33,3\% responden menjawab kurang setuju dengan pernyataan bahwa pemahaman dan pengalaman yang didapat dari praktikum virtual lab lebih baik dari pada reality lab. Penerapan virtual lab yang tidak secara nyata melakukan praktikum dengan alat dan bahan yang sesungguhnya akan mengurangi keterampilan dan pengalaman praktikan, jika dibandingkan dengan praktikum reality lab.

\section{Pertanyaan 7}

Pemahaman dan pengalaman yang didapat dari praktikum rality lab lebih baik dari pada virtual lab?

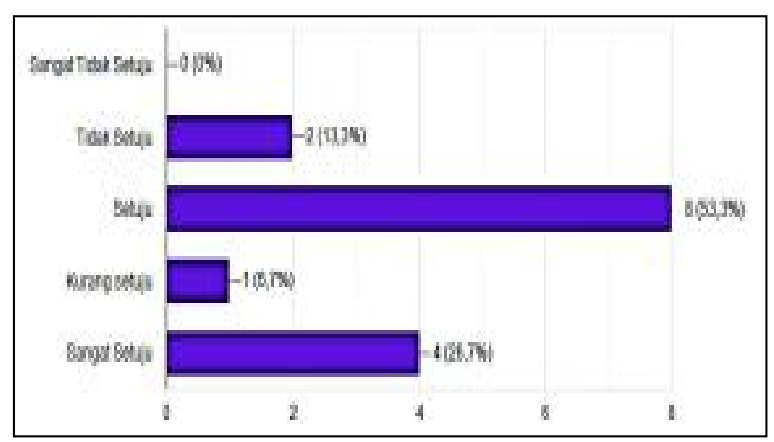

Gambar 9. Diagram Hasil Survei Pertanyaan 7 
Penjelasan: Sebanyak 53,3\% responden menjawab setuju dengan pernyataan bahwa pemahaman dan pengalaman yang didapat pada praktikum reality lab lebih baik dari pada virtual lab. Secara teknis praktikum reality lab akan meningkatkan pemahan dan pengalaman praktikan, hal ini didasarkan pada kemampuan motorik praktikan yang secara real melakukan praktikum dari awal hingga akhir dengan segala kejadian-kejadian yang meliputinya, seperti kemampuan menyelesaikan permasalahan yang terjadi selama praktikum.

\section{KESIMPULAN}

Penelitian analisis perbandingan penerapan virtual lab versus reality lab terhadap 15 sampel mahasiswa Universitas Singaperbangsa Karawang memberikan kesimpulan bahwa: Penerapan virtual lab dapat mengurangi kesalahan dan kecelakaan kerja saat praktikum, hal ini didukung dengan hasil survei $\quad 80 \%$ sampel menjawab setuju, $20 \%$ menjawab sangat setuju pada pertanyaan nomer 4 , selain itu penerapan virtual lab juga dapat menjadi solusi bagi perguruan tinggi yang memiliki permasalahan dengan fasilitas laboratorium, hal ini didukung oleh hasil survei $60 \%$ sampel menjawab setuju dan 33,3\% sangat setuju pada pertanyaan nomer 2, namun virtual lab tidak bisa diterapkan secara penuh menggantikan reality lab, hal ini dikarenakan tingkat pengalaman dan keterampilan praktikan dengan virtual lab tidak sebaik dengan reality lab, hal ini didukung oleh hasil survei 33,3\% sampel menjawab kurang setuju, 26,7\% tidak setuju dan $13,3 \%$ sangat tidak setuju dengan pernyataan nomer 6. Praktikan tidak secara langsung berinteraksi dengan alat dan bahan kimia, sehingga virtual lab lebih efektif jika diterapkan sebagai prepraktikum atau praktikum pendahuluan untuk menunjang pemahaman praktikan dalam melakukan praktikum sebagaimana jawaban sampel pada pertanyaan nomer 3 dengan presentase 93,3\% menjawab setuju dan 13,3\% sangat setuju.

\section{UCAPAN TERIMAKASIH}

Penulis mengucapkan terimakasih kepada Lembaga Penelitian dan Pengabdian (LPPM) Universitas Singaperbangsa Karawang yang telah memberikan dana Hibah Internal DIPA UNSIKA 2019 sehingga bisa terlaksananya penelitian ini

\section{DAFTAR PUSTAKA}

[1] N. Hikmah, N. Saridewi, and S. Agung, "Penerapan Laboratorium Virtual untuk Meningkatkan Pemahaman Konsep Siswa," EduChemia (Jurnal Kim. dan Pendidikan), vol. 2, no. 2, p. 186, 2017.

[2] F. Tua, M. Panggabean, K. Sihombing, and M. Simorangkir, "KIMIA BERBENTUK VIRTUAL LAB," no. September, pp. 2010-2013, 2017.

[3] F. Peserta, D. Kelas, X. I. Mia, and S. Makassar, "Penerapan Perangkat Pembelajaran Berbasis Laboratorium Virtual Pada Pencapaian Hasil Belajar," no. April, pp. 16-22, 2018.

[4] H. Jaya, "Pengembangan Laboratorium Virtual Untuk Virtual Laboratory Development for Practicum and Facilitating Character Education in Vocational High," Pengemb. Lab. Virtual Untuk Kegiat. Prakt. Dan Memfasilitasi Pendidik. Karakter Di Smk, vol. Vol 2, pp. 81-90, 2012.

[5] J. S. No, "Peranan Praktikum Riil Dan Praktikum Virtual Dalam Membangun Kreatifitas Siswa," pp. 92-102, 2012.

[6] S. R. Muzana, P. Studi, P. Fisika, U. Abulyatama, and U. Abulyatama, "PENERAPAN LABORATORIUM VIRTUAL TERHADAP HASIL BELAJAR FISIKA PADA MATERI RANGKAIAN ARUS BOLAK-BALIK SISWA KELAS XII."

[7] A. Setiawan, A. Suhandi, I. Kaniawati, J. S. No, F. Keguruan, and U. Bengkulu, "Model Higher Order Thinking Virtual Laboratory: Model Praktikum Fisika Berbasis Keterampilan Berpikir Kritis Dan Pemecahan Masalah," vol. 3, no. 5, 2018.

[8] J. I. Bintaro and T. Kusir, "PENERAPAN ELEARNING DI PERGURUAN TINGGI Santi Maudiarti Sekolah Tinggi Pariwisata Trisakti," vol. 32, no. 1, pp. 53-68, 2018. 
